\title{
Liaoning Progressing in Innovation Needs to Speed up Cultivating Talents of the Equipment
}

\author{
Yang Xia, Hu Yan, Liu Guiqiu, Dai Zhaohui \\ Electric Engineering College of Shenyang University of Technology \\ Shenyang 110870
}

\begin{abstract}
The purpose of this study is to train the necessary equipment manufacturing talents for the old industrial base, Liaoning, which is going forward in innovation. This requires cooperation among the government, universities, enterprises and research institutes. Colleges and universities, as the main body of training talents, inject scientific research into the training system, and together with the support of the government. As long as the correct development and train of thought, we can provide a strong talent support for the development of Liaoning equipment manufacturing industry. Then, the revitalization of Liaoning's equipment manufacturing industry can be achieved completely.
\end{abstract}

Keywords—Equipment manufacturing; Skills; Training

\section{INTRODUCTION}

The traditional manufacturing skilled talents has been unable to adapt to the needs of their innovation and development, while the innovative high skilled talents are the propellant of the new industrialization enterprises, and the important guarantee of innovation sustainable ability. Faced with this demand, higher education must be actively explored and implemented in the aspects of personnel training mode, teaching system and curriculum content reform, work study combination, etc. Advanced manufacturing technology is the key development area of the country, whose core is advanced manufacturing equipment. The equipment manufacturing industry in Liaoning as the revitalization of the equipment manufacturing industry planning and the supporting objects for the revitalization of northeast old industrial base planning, which is responsible for the important task of developing autonomous technology, enhancing the ability of independent innovation, improving the level of industrial technology and promoting economic development.

Now, with the rapid development of science and technology and change rapidly of manufacturing equipment, not only requires a lot of application-oriented skills, but also more and more innovative talent. Therefore, the development of equipment manufacturing industry in Liaoning, especially in the advanced equipment manufacturing industry, it is necessary to strengthen the reform of the training of innovative talents with the cooperation of universities, and the government should increase the policy support and financial investment in this area.

Project: Research project of undergraduate teaching reform of general higher education in Liaoning in 2016:Practical Research of Construction of high quality teaching resources and Intercollegiate elective courses,2016 Provincial undergraduate education reform project quality education resources sharing and construction projects: Research and practice of the sharing of high-quality teaching resources and intercollegiate elective courses based on the course of "Electrical Control Technology commonly used".

\section{THE SignificAnCE OF CUltivating TALENTS IN EQUIPMENT MANUFACTURING INDUSTRY}

\section{A. The necessity of training innovative talents in equipment manufacturing industry}

National policy and government planning have laid the foundation for training innovative talents in equipment manufacturing industry.

Fourth chapters and second sections of "12th Five-Year plan" for the revitalization of Northeast China: Actively promote regional collaborative innovation. Integration of innovation resources. To construct an innovation network consisting of enterprises, universities, scientific research institutions and scientific and technological service institutions, and to support the establishment of industrial technology innovation alliance. Around the key technology nodes in the industry chain should overall coordination and collaborative tackling key problems, to achieve breakthroughs in key technologies and core technologies. The fourth chapter third section: Building a contingent of high-quality innovative talents. Organization and implementation of major personnel projects, to explore the talent evaluation index system with the performance as the key point and which is composed of the elements of morality, knowledge, ability and so on. We should improve the incentive mechanism of technology, knowledge, management and other factors to participate in the distribution, and support and encourage the enterprises to adopt the distribution system suited to their own characteristics. And comprehensively enhance the ability of cultivating innovative talents. To support universities and scientific research institutions as pilot projects to actively carry out the cultivation of top-notch innovative talents. To improve the conditions of running a school and scientific research and innovate the idea of running a school and scientific research, and make the universities and scientific research institutions become the cradle of cultivating innovative talents. Strengthening discipline construction, innovating education and teaching methods, and further improving the quality of education [1].

The State Council's reply to the plan for the revitalization of Northeast China in 12th Five-Year has such a directive: Efforts should be made to break through the institutional, institutional and structural contradictions restricting the revitalization of the northeast, and promoting the continuous 
innovation of the system and mechanism; Efforts should be made to speed up the adjustment and transformation of the old industrial bases in Northeast China, promoting greater progress in economic restructuring; Efforts to enhance scientific and technological innovation ability, and promoting the quality and efficiency of regional development to further enhance; Efforts should be made to ensure and improve people's livelihood, promoting cultural and social undertakings in an all-round way; Efforts should be made to strengthen ecological construction and environmental protection, promoting the level of ecological civilization. We should continue to implement the overall strategy of regional development and the planning of the main functional areas. We should give full play to the characteristics and advantages of the northeast region, promote the benign interaction and coordinated development of regional economy, and lay a solid foundation for the realization of the goal of building a well-off society in an all-round way [2].

Liaoning is in a critical period of expanding domestic demand, speeding up infrastructure construction and industrial transformation and upgrading, and has a huge market demand for advanced equipment; The financial crisis has accelerated the adjustment of the world industrial structure, thus providing more opportunities for the industry to re division of labor in Liaoning. Although the fundamentals of the development of equipment manufacturing industry has not changed, but we must take corresponding measures to seize the opportunity to speed up the adjustment of industrial structure, strengthen technological innovation, promote the equipment manufacturing industry sustained and stable development, contribute to the rapid economic development smoothly.

Therefore, speeding up the cultivation of high-quality innovative talents is the guarantee of the revitalization of the equipment manufacturing industry, which is of great significance.

\section{B. The foundation and advantage of training innovative talents in equipment manufacturing industry}

More than 50 years after the founding of the People's Republic of China, especially in the past more than 20 years of reform and opening up. China has formed a system of equipment manufacturing industry, which has a complete range and a considerable scale and level. Equipment manufacturing industry has become an important pillar industry of China's economic development, manufacturing scale has leapt to the fifth place in the world. It can be said that China has become a major manufacturing country in the world. However, we must clearly realize that the overall quality of China's manufacturing industry is not high, still far from the level of the world manufacturing power. Compared with the developed countries, our independent innovation ability is still very weak. There are such problems as lack of independent intellectual property rights, industrial main technology rely on foreign countries, lack of international competitiveness. Revitalization of equipment manufacturing industry needs to solve many problems, two of them are the most prominent and the most critical issues, one is to achieve industrial structure optimization and upgrading, and two is to improve the ability of independent innovation. And these two are interrelated. Improving the ability of independent innovation is the guarantee to realize the optimization and upgrading of industrial structure. The basis of independent innovation ability is talents. So, in the final analysis, the core issue is how to train innovative talents in the equipment manufacturing industry [3-4].

The development of equipment manufacturing industry can promote the overall quality of our citizens and speed up the process of modernization, which is the need to improve economic efficiency and improve the level of service socialization and specialization. The development of equipment manufacturing industry promotes the development of the third industry at the same time, which can effectively promote the process of industrialization and modernization in china. These are inseparable from the related innovative talents and the cultivation of these talents. Only in this way can we form a good cycle of manufacturing and personnel training, and then we can truly revitalize the equipment manufacturing industry in Liaoning [5].

\section{CULTIVATION OF TALENTS IN EQUIPMENT MANUFACTURING INDUSTRY}

\section{A. Cultivation of innovative scientific and technological talents}

1) The cultivation of innovative talents of science and technology is based on Colleges and universities, relying on the old industrial bases.

Taking Shenyang University of Technology as an example the Shenyang University of Technology is located in the historical and cultural heritage, the strong vitality of economic and social development of the old industrial city - Shenyang in Liaoning Province, is a covering science, engineering, management and other disciplines of the university. The school has "Liaoning Province rare earth permanent magnet motor engineering technology center" and "Shenyang wind power engineering technology center" and "National 863 program achievement industrialization base", equipped with modern testing and motion control experiment center, intelligent systems and computer control experimental center, high voltage and high current laboratory, power electronics converting technology laboratory, DSP development and application laboratory, manufacturing technology lab, precision measurement laboratory, laboratory of fluid drive Laboratory, vibration and noise laboratory, wind energy technology research institute, special motor research laboratories and various machines, electrical laboratories and research institutes, etc.. According to the demand of the application of innovative talents in the development of manufacturing industry in the old industrial base of Liaoning Province, the training ability of innovative talents in Colleges and universities should be improved. And has the ability to shoulder the glorious mission of training the equipment manufacturing talents. 
a) Training of teachers' engineering practice ability and scientific research ability

University teachers are the main body of running colleges and universities, and they are the direct undertaker of personnel training, subject construction, teaching reform and scientific research. Colleges and universities should shoulder the mission of training high-quality innovative talents to adapt to the development of modern society, and play the social service function of promoting scientific and technological innovation and civilization inheritance. It has to build a high level teacher team with noble morality, consummate business, moderate scale, optimized structure, relatively stable, lean and efficient, combination of specialization and consideration and innovative spirit and vigor.

Developing a system for teacher training and training in rotation. Teachers should conduct regular training among colleges and universities, and enterprises to participate in the project practice, to enhance the ability of Engineering practice. In this way, through theoretical, practical training and enterprise visit, that is, on-site visits to new products and hightech, can better enhance the engineering practice and scientific research ability of teachers. Thus, cultivating a team of engineering and scientific research ability, high level of teaching, teachers can adapt to the need of engineering education reform and development, which can really responsible for the revitalization of the equipment manufacturing industry in Liaoning to cultivate innovative talents.

\section{b) Injecting scientific research into Teaching}

To promote teaching with scientific research, and to inject scientific research results and research thinking into theoretical teaching and experimental teaching. By attracting students to participate in cutting-edge research, and then students will be brought into the platform of scientific and technological innovation. To help students broaden their horizons of knowledge, develop scientific thinking methods, and improve their practical and innovative ability. In order to cultivate high quality talents with engineering practice ability and pioneering and innovative ability. We should encourage students to actively participate in various scientific and technological competitions as well as teachers' research projects.

A special lecture will be given by the doctoral supervisor, academic leaders and technical experts of equipment manufacturing enterprises, which will introduce the latest and most advanced technology and development trend of equipment manufacturing industry.

Undergraduate graduate design and research projects combined to make the topic as much as possible to reflect the latest level of equipment manufacturing technology. So that students can be based on the forefront of discipline development, on this account, training students with engineering practice and pioneering and innovative ability.

\section{c) Dynamic teaching and innovative practice}

The training of students' practical ability and innovative ability should be focused on the combination of reasonable knowledge structure, foresight and practicability, so as to meet the needs of market and the development of equipment manufacturing industry. It is one of the important ways to improve the quality of personnel training by using the experimental link to carry out innovative education and cultivate students' innovative consciousness and innovative ability.

2) Equipment manufacturing industry independently cultivate and absorb the leading talents at home and abroad

On the basis of independent innovation of university personnel training, the equipment manufacturing industry leader will in self-training or the introduction of a number of talents, who with in the leading position in the domestic and international influence in the science and technology leading talent, engineers and high level creative team. On training of young scientific talents and innovative talents, to improve the professional level and innovation ability as the core, with high level talent and talent shortage as the focus, and strive to build a strong innovation ability, with reasonable structure and high quality talents in science and technology.

\section{B. The cultivation of applied vocational technical talents}

Applied talents are the foundation of Liaoning equipment manufacturing industry and innovative talents training in the old industrial base, as well as the inevitable demand of regional economic development.

Applied talents refer to a special type of talents who can apply professional knowledge and skills to professional social practice. They are mainly engaged in front-line production of technical or professional personnel, with skilled basic knowledge and basic skills to master the social production or social activities front.

In order to train applied talents, colleges and universities should carry out autonomous learning ability training in teaching methods and methods, emphasizing practicability, practicality, comprehensiveness and teamwork. For example, in the mechanical processing, mainly focused on: proficient in mechanical processing and $\mathrm{CNC}$ machining process knowledge, and be good at the operation and programming of CNC machine tools and so on.

In addition, schools and enterprises cooperate with each other to set up colleges to train professional talents for the enterprise. According to the specific needs of the enterprise, teach students in accordance with their aptitude, and often practice in the enterprise, to improve students' hands-on ability and skills. When the students graduate, they will be directly employed by the enterprise. Joint training of enterprises and universities, not only can clear the purpose and aim of cultivating talents in higher education, improve the students' skills and employment rate, but also save a lot of cost for the enterprise, and reserves a large number of full-time personnel. This is a mutually beneficial measure [6-7].

At the same time, the government departments should attach great importance to the cultivation of applied talents, 
study and formulate the optimization strategy of human resources structure, and ensure the matching of talent training and the demand for the development of Liaoning equipment manufacturing industry.

\section{Construction of talent training platform}

The development mechanism of skilled talents is realized through the support of institutions and social participation, with the government and enterprises as the main body. Using the existing educational resources, relying on large backbone enterprises and key institutions, to build the base with highperformance personnel training and public practical training. At the same time, the research results will be integrated into classroom teaching, taking great pains to explore the potential of scientific and technological innovation of College students. It is important for students to better understand and master the knowledge they have learned, to broaden their horizons, to understand the frontiers of disciplines, to cultivate and cultivate innovative consciousness. To support qualified enterprises to establish post-doctoral mobile stations, enterprises and technical centers, and encourage universities, research institutions and enterprises to jointly establish research and development institutions. With the development and construction projects as a platform for domestic and international bidding recruiting, accelerate talent aggregation.

\section{CONCLUSION}

Under the leadership of Liaoning provincial Party committee and provincial government, the overall thinking of the development of Liaoning equipment manufacturing industry has been clear, that is, to establish a strategic vision of the world vision, using Chinese equipment to support China made. Taking Scientific Outlook on Development as the guiding ideology. It should aim at improving the major equipment and technology, independent research and development of high-tech equipment design, manufacturing and system integration level. We must firmly grasp the strategic opportunity of revitalizing the northeast old industrial base, accelerate structural adjustment and system innovation. To achieve industrial clusters, technical automation, equipment package, marketing internationalization, and comprehensively promote industrial upgrading. At the same time, we should soberly recognize the situation faced by the equipment manufacturing industry in Liaoning, and attach importance to the gap and problems existing in the equipment manufacturing industry. As long as the correct development strategy and train of thought are adopted, it will provide strong talent support for the development of Liaoning equipment manufacturing industry. The revitalization of Liaoning equipment manufacturing industry can be realized completely.

\section{REFERENCES}

[1] 12"12th Five-Year plan for the revitalization of Northeast China". National Development and Reform Commission.

[2] The State Council's reply to the plan for the revitalization of Northeast China in 12th Five-Year, State Council, state letters [2012] No. 17.

[3] Jia Chengbing. "vigorously promote the 653 project to provide personnel protection for the revitalization of equipment manufacturing industry ", the modern manufacturing field "653 project" working conference, 2007.

[4] Ding Yaomin. To promote the equipment manufacturing industry technological innovation [J]. China Trade Herald, 2008, (6).

[5] Shang Xiaodan. Study on Promoting Technology Innovation Ability of Equipment Manufacture in Liaoning Province [D]. Jilin University, 2007.

[6] Guo Ying. The implementation of the "learning and working combination" training model to improve the competitiveness of students employment [J]. China Vocational and technical education, 2008, (18).

[7] Ye Hua, etc..A Brief Discussion on the Construction of Professional Teaching Team with the Combination of Learning and Work [J]. vocational education research.2008 (5). 